\title{
IMPROVEMENT OF SILVER IMPREGNATION TECHNIQUE (PROTARGOL) TO OBTAIN MORPHOLOGICAL FEATURES OF PROTISTS CILIATES, FLAGELLATES AND OPALINATES
}

\author{
SILVA-NETO, I. D. da \\ Laboratório de Protistologia, Departamento de Zoologia, Instituto de Biologia, C.C.S., Universidade Federal do Rio \\ de Janeiro, Ilha do Fundão, CEP 21941-590, Rio de Janeiro, RJ, Brazil \\ Correspondence to: Inácio Domingos da Silva-Neto, Laboratório de Protistologia, Departamento de Zoologia, \\ Instituto de Biologia, C.C.S., Universidade Federal do Rio de Janeiro, Ilha do Fundão, CEP 21941-590, \\ Rio de Janeiro, RJ, Brazil \\ Received December 10, 1998 - Accepted October 25, 1999 - Distributed August 31, 2000
}

(With 13 figures)

\begin{abstract}
The research on ciliates, flagelates and opalinates have been widespread by the utilization of techniques employing silver impregnation (Protargol), modified by several authors. However, these are time consuming and its results are variable. The present work is a variant of the technique described by Tuffrau (1964, 1967) showing some adaptations made in our laboratory. The organisms can be preserved by different fixatives (alcoholic Bouin, Stieve's fluid, 2.5\% glutaraldehyde and others) and then rinsed in destilled water followed by a fast clarification by $3 \%$ sodium hypochloride. If the organism is very sensitive to hypochloride, $4 \%$ sodium lauryl sulfate may be used and then washed 3 times in distilled water. The protista can be adhered to the glass slides with Mayer's glycerinated-albumin (1 glycerin vol. to 1 or 2 albumin vol.), diluted in water at a proportion of $1: 10 \mathrm{Cv} / \mathrm{v}$., or with $1 \%$ polylysine followed by fast washes with distilled water. After the slide preparation, they were covered with a layer of $0,8 \%$ Silver proteinate. Right after that, the slide has to be placed in a glass tray lined with moist tissue and covered to prevent the proteinate to dry. The tray was placed in a incubator at $40^{\circ}$ $50^{\circ} \mathrm{C}$ for 30 minutes. The slides are rinsed for 1 minute. with warm $\left(35^{\circ} \mathrm{C}\right)$ distilled water. The development of the material should be done with $0.4 \%$ hydroquinone with a maximum incubation time of 1 minute. It should be developed gradually, controlling the silver impregnation intensity by observation under optical microscope. Next, rinse in distilled water for 1 minute, and then, fix in 2,5\% Sodium thiosulfate. Rinse the slide for two minutes before dehydrating it in an alcoholic serial $50-100^{\circ}$. Finally rinse the slides in xylene. Mount the slides with Entellan MerckTM or Canada balsam.
\end{abstract}

Key words: impregnation of protists, protargol, technique improvement.

\section{RESUMO}

Aperfeiçoamento da técnica de impregnação pela prata (protargol) para obtenção de caracteres morfológicos de protistas ciliados, flagelados e opalinatas

A pesquisa sobre ciliados, flagelados e opalinatas vem sendo ampliada com utilização da técnica de impregnação pela prata (protargol), modificada por vários autores. Mas, geralmente, estas demoram muito para se desenvolver e os resultados são variados. O presente trabalho é uma variante da técnica descrita por Tuffrau (1964, 1967), mostrando algumas modificações feitas no laboratório. Os organismos podem ser preservados por diferentes fixadores (Bouin alcóolico, solução de Stieves, glutaraldeído a $2,5 \%$ e outros), lavados com água destilada e em seguida clarificados com hipoclorito de sódio a $3 \%$. Se o organismo é muito sensível ao hipoclorito, podemos fazer uso do lauril sulfato 
de sódio a 4\% e 3 lavagens com água destilada. Os protistas são aderidos à lâmina com albuminaglicerinada de Mayer (1 vol. glicerina para 1 ou 2 vol. albumina), diluída em água na proporção de 1:10, ou com polilisina a $1 \%$. Depois da preparação e secagem das lâminas, estas são cobertas por uma fina camada de proteinato de prata a $0,8 \%$. Logo após, as lâminas são colocadas em uma tigela retangular contendo, no fundo, papel umidecido e uma tampa para evitar o ressecamento do proteinato. A tigela é posta em uma estufa a $40^{\circ}-50^{\circ} \mathrm{C}$ por $30 \mathrm{~min}$. As lâminas são lavadas por 1 minuto com água destilada morna $\left(35^{\circ} \mathrm{C}\right)$. A revelação do material deve ser feita pela hidroquinona a $0,4 \%$ por, no máximo, 1 minuto, controlando gradualmente a intensidade da impregnação pela prata por meio da observação em microscópio óptico. Em seguida, lavar em água destilada por 1 minuto para rapidamente fixar em tiossulfato de sódio a 2,5\%, lavar novamente a lâmina por dois minutos antes da desidratação em série alcóolica $50-100^{\circ}$ e, finalmente, três banhos em xileno. Montar as lâminas com Entellan MerckTM ou bálsamo do Canadá.

Palavras-chave: impregnação de protistas, Protargol, aperfeiçoamento de técnica.

\section{INTRODUCTION}

The silver proteinate impregnating technique (Protargol) offers great results and many advantages among other silver-based impregnation techniques used for optical microscopy. Its results show in great detail morphological key features of ciliates, flagellates and opalinates.

Researches with protists of several environments have been increased using the protargol, which is an impregnation, not a coloration technique, whose impregnating agent is the silver proteinate. Several authors (Dieckerman, 1995; Foissner, 1991; Dragesco \& Dragesco-Kernéis, 1986; Wilbert, 1975) have modified the primary technique of Bodian $(1936,1937)$ with the aim of obtaining satisfactory results, but these generally take a long time to develop.

The present work is a variation of the technique of protargol described by Tuffrau $(1964,1967)$ and was made with some modifications in the laboratory. The primordial objective was to get satisfactory results in a relatively short time and to process numerous slides with a reduced expense of silver proteinate.

The photomicrographs of the boards presented in this work were made using the technique described below. The boards show the improved structural details of the cortex and endoplasma of a flagellate, of an opalinate and of ciliates of different environments and which belong to several groups (Karyorelictea, Gymnostomatida, Prostomatida, Peniculina, Colpodida, Heterotrichida and Hypotrichida). For the identification of these organisms it is necessary to make the somatic and oral infraciliature evident, as well as the form of the macro and micronucleus. A brief comparison of the technique of protargol with other techniques that use silver salts as impregnating agent is made.

\section{MATERIAL AND METHODS}

The ciliates Tracheloraphis phenicoptera, Coleps sp. and Diophrys appendiculata were collected from Baía de Guanabara, Rio de Janeiro; Lacrymaria olor and Spirostomum minus were collected in bromeliad; Colpoda cucullus was collected, in form of cysts, from the filter in the air conditioner of the laboratory. Paramecium aurelia and Euplotes woodruffi were collected from Lagoa de Piratininga in Niterói. Fabrea salina was collected from Lagoa de Araruama in Rio de Janeiro. Trichonympha sp. was isolated from digestive apparatus of termites. The opalinates were isolated from the digestive apparatus of tadpoles Physalaemus signifer.

The ciliates were cultivated in petri dishes with rice or wheat grains, except the opalinates and flagellates. The fixatives used were: $2 \%$ Osmiun tetroxide (T. phenicoptera), alcoholic-Bouin (D. appendiculata and Coleps sp.), Stieves' solution(L. olor, S. minus, C. cucullus, P. aurelia, E. woodruffi and $F$. salina) and 2,5\% glutaraldehyde (Trichonynpha sp. and the Opalinata).

Alcoholic-Bouin: $150 \mathrm{ml} 80 \%$ alcohol +60 $\mathrm{ml}$ formaldehyde PA $+1 \mathrm{~g}$ of picric acid $+15 \mathrm{ml}$ glacial acetic acid. This is an excellent fixative, one of its advantage is facilitating attaching the ciliates in the bottom of the clock glass, facilitating the subsequent washes. 
Solution of Stieves: (modified by Foissner, 1991); 3,8 $\mathrm{ml}$ of aqueous mercury chloride (dissolve $30 \mathrm{~g} \mathrm{HgCl} 2$ in $500 \mathrm{ml}$ of hot distilled water) + $2 \mathrm{ml}$ of commercial formaldehyde PA $+0,3 \mathrm{ml}$ of concentrated glacial acetic acid. freshly prepared; the components can be stored.

Glycerinated-albumin of Mayer: For the preparation of the Glycerinated-Albumin of Mayer is recommended the use of two chicken eggs. Remove the albumin of the egg and filter through a nylon filter and mix $30 \mathrm{ml}$ of the filtered albumin with $20 \mathrm{ml}$ of glycerin; add 3 drops of formaldehyde PA to avoid the contamination of the material.

$1 \%$ hydroquinone: place $2,5 \mathrm{~g}$ of sodium sulfite in $50 \mathrm{ml}$ of distilled water, dissolve, and later add $0,5 \mathrm{~g}$ of hidroquinone.

\section{STEPS OF THE TECHNIQUE:}

\section{1) Isolation and fixation of the specimens.}

1.1) Under a stereoscopic microscope with transmitted light, the ciliates, flagellates or opalinates should be isolated and taken out from a Petri dish and transfered to a small glass recipient or a glass slide with the aid of a micropipete.

1.2) The ciliates, separated with little water, can be fixed with alcoholic Bouin, solution of Stieves or with $2,5 \%$ glutaraldehyde and $2 \%$ osmium tetroxide, for 20 minutes. The kind of fixative can vary according to the species.

1.3) Immediately after fixing, wash the specimens three times in distilled water.

\section{2) Clarification and cleaning of the cells.}

2.1) To clarify and remove fragments of organic matter attached to the cells, add in the last two washes, two or three drops of 3\% sodium hipochloride. Mix and incubate for about 30 seconds, but control the clarification under the magnifying glass, to avoid the bursting of the cells and then wash three times or more. If necessary, repeat the clarification, leaving the cells less time in the hipochloride. For some more sensitive protists $4 \%$ sodium lauryl sulfate can be used for the cleaning of the cells.

2.2) After the cleaning and clarification, the cells should be distributed in degreased slides. Add on the cells a small drop of glycerinated albumin of Mayer solution (albumin of egg + glycerin in the proportion of $1: 1$ or $2: 1$ ), diluted before use with distilled water in the proportion $1: 10$, to avoid albumin excess in the final preparation. The material should be spread to be well homogenized and left to dry in ambient temperature, for several hours, or in incubator at 40 to $50^{\circ} \mathrm{C}$. For obtaining success it is important to use the minimum of albumin to attach the cells.

The albumin dipped in the distilled water can also be placed in a small watch glass recipient, on the clarified cells, before distributing them in the slides. $1 \%$ polylysine in PBS can also be used to attach the cells on the slides. Later proceed a wash in a staining jar with distilled water and then, without drying the preparation, cover the cells with silver proteinate, as in the stage 3.

\section{3) Impregnation and development of the specimens.}

3.1) Before covering the cells with silver proteinate, cover the preparation with a mixture of alcohol-formoldehyde in the proportion of 8:2. Let it act during one minute and wash it with distilled water for two minutes. This procedure avoids the detachment of the cells during the processing of the technique.

Use a rectangular glass tray, with a lid and cover the bottom with moisten filter paper. Distribute the dry slides with the ciliates attached to them on the bottom of the tray and using a Pasteur pipette cover the preparations with drops of $0,8 \%$ or $1 \%$ silver proteinate. Place the covered tray in the incubator at $45^{\circ} \mathrm{C}-50^{\circ} \mathrm{C}$, for 30 to 60 minutes, depending on the size of the protozoan. It is advisable to avoid the total evaporation of the silver proteinate of the preparation.

3.2) Remove the tray from the incubator to process the revelation of the slides, one at time. Wash the slide quickly in distilled water and quickly place it in a staining jar with $0,4 \%$ hydroquinone to reveal the preparation for 10 to 20 seconds. After brief wash in distilled water, an observation is done under the microscope to control impregnation. If necessary, it can be left more time in the developer, which can vary in concentration.

3.3) After reaching the desired impregnation, place the slide for about 30 seconds in the $2,5 \%$ sodium thiosulfate, to fix the impregnation. If the impregnation of the cells decreases, return it to the developer.

3.4) After passing it in the sodium thiosulfate, wash the slide for one minute in distilled water and begin the dehydration with alcoholic series from $50 \%-100 \%$ and finally in three jars with xylene. 


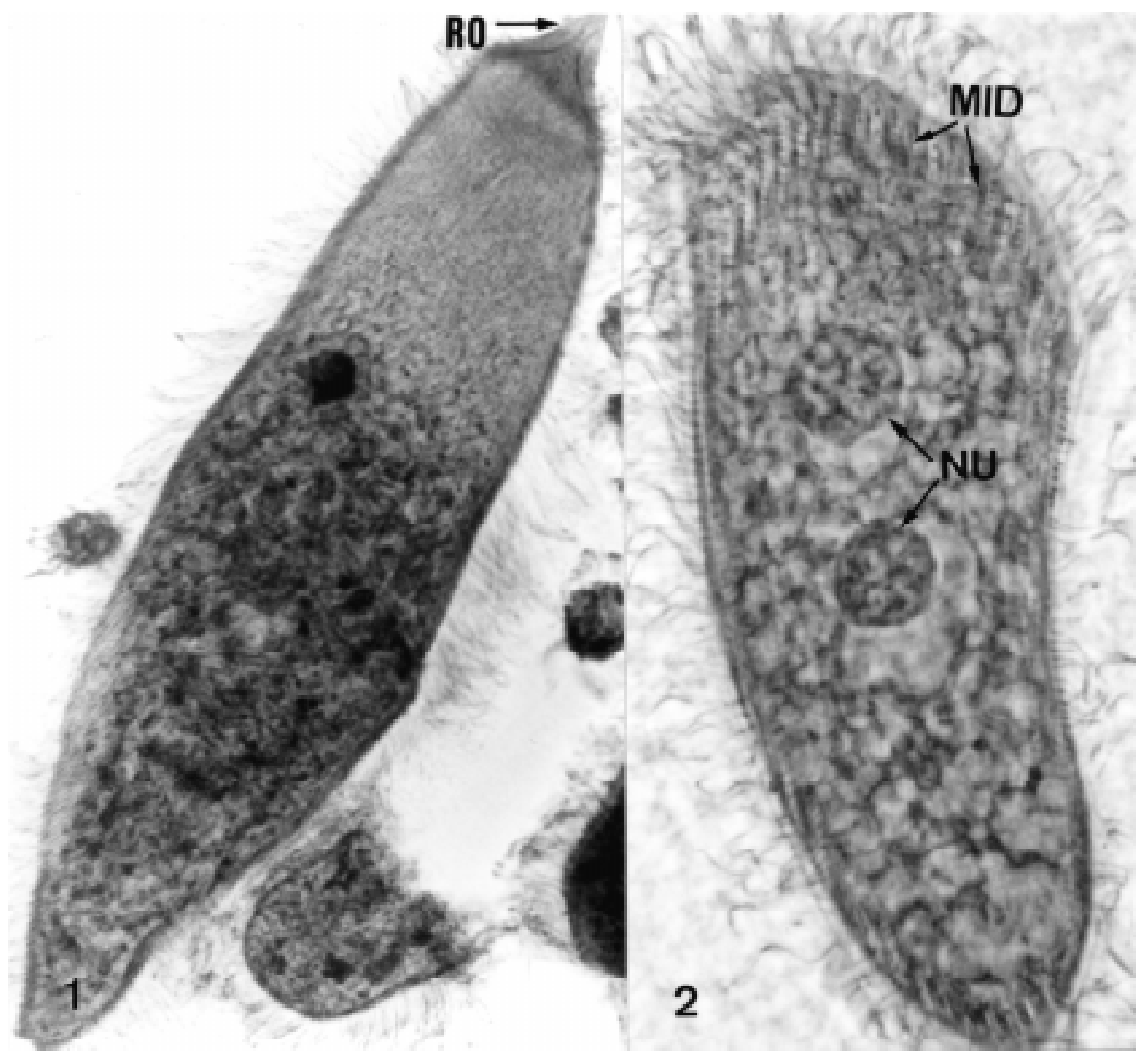

Fig. 1 - Protargol impregnated of Trichonympha sp. Simbionte flagelated into digestive apparatus of termite. General view body. RO - rostre. Fig. 2 - Protargol impregnation of a Opalinata found from digestive apparatus of the little toad, Physalaemus signifer, collected at Tijuca's Woods, Rio de Janeiro. NU - nucleus, MID - Microfibrilar Interkinetians Derived.

Set up the slides covering the preparation with two drops of Entellan Merck or in diluted balsam from Canada, before placing the coverslip.

\section{DISCUSSION}

The silver impregnation technique (protargol) offers for optical microscopy the best results in the revelation of morphologic characteristics of the structures of the cortex and endoplasma, as well as the form and disposition of the nuclei of protista ciliates, flagellated and opalinates.
The silver proteinate, used in the technique, acts as an impregnanting agent, on the level of the kinetossomes or basal corpuscles of the cilia and flagellum. With the impregnation of these it is placed in evidence the distribution of the somatic kineties and organization of the cilia and flagellum of the oral area of the protozoan, facilitating the counting and description of its components.

The modifications and improvements of the protargol technique started with the results presented by Bodian $(1936,1937)$, who used the technique for the revelation of cells of the nervous tissue. 

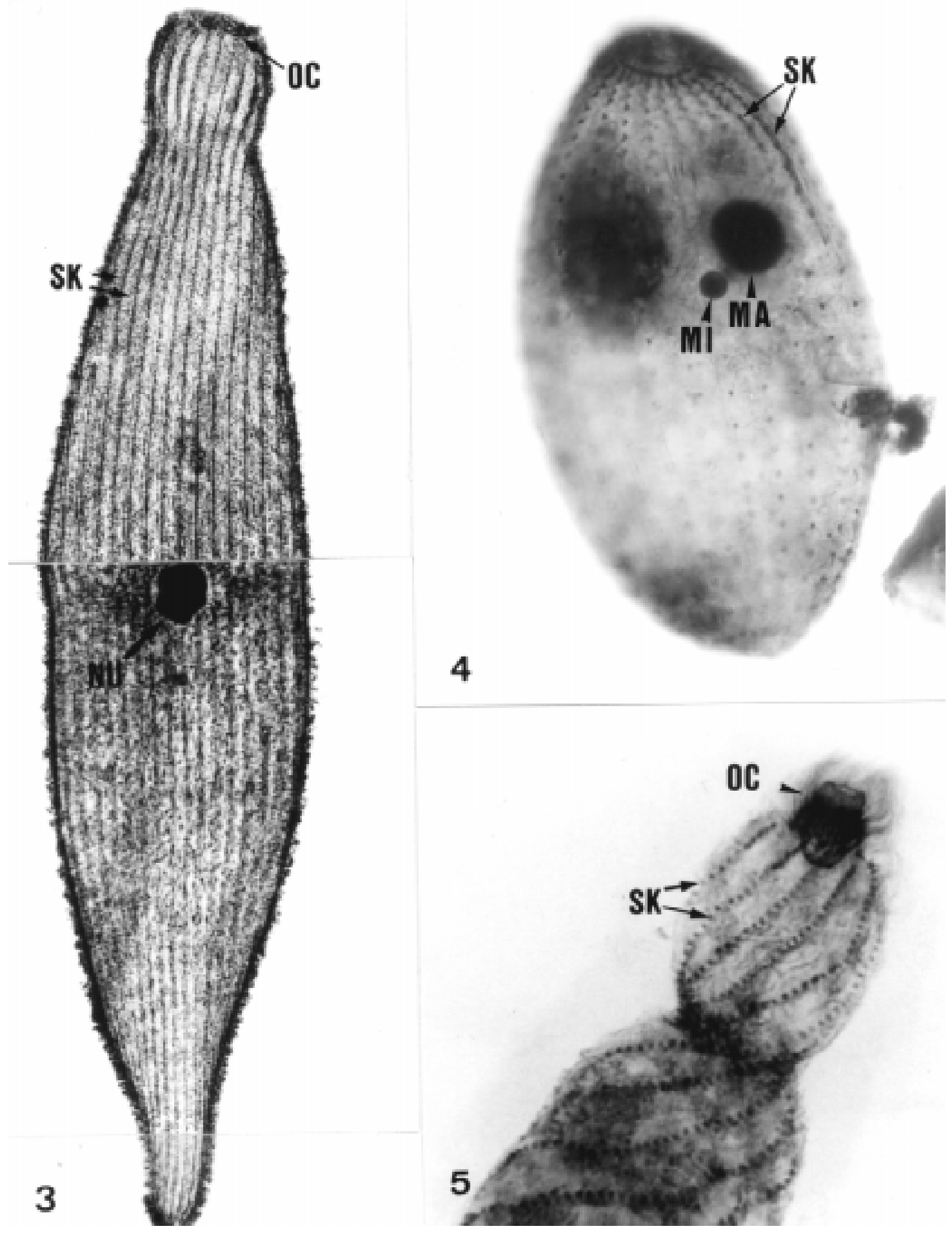

Fig. 3 - Protargol impregnation of Tracheloraphis phenicoptera. Photo assemble of the Karyorelictea ciliate from Baía de Guanabara, Rio de Janeiro. View body and detail of oral and somatic ciliature. NU - Nuclear Apparatus, OC - Oral Ciliature, SK - Somatic Kineties. Fig. 4 - Protargol impregnation of Coleps sp. Prostomatida ciliate from Baía de Guanabara, Rio de Janeiro. SK - Somatic Kineties, MA - Macronuclei and MI - Micronucleus. Fig. 5 - Protargol impregnation of Lacrymaria olor. Gymmostomatida ciliate from fresh water. Anterior view body. The Somatic Kineties (SK) are spiral form due cell contraction after fixation. OC - Oral Ciliature 

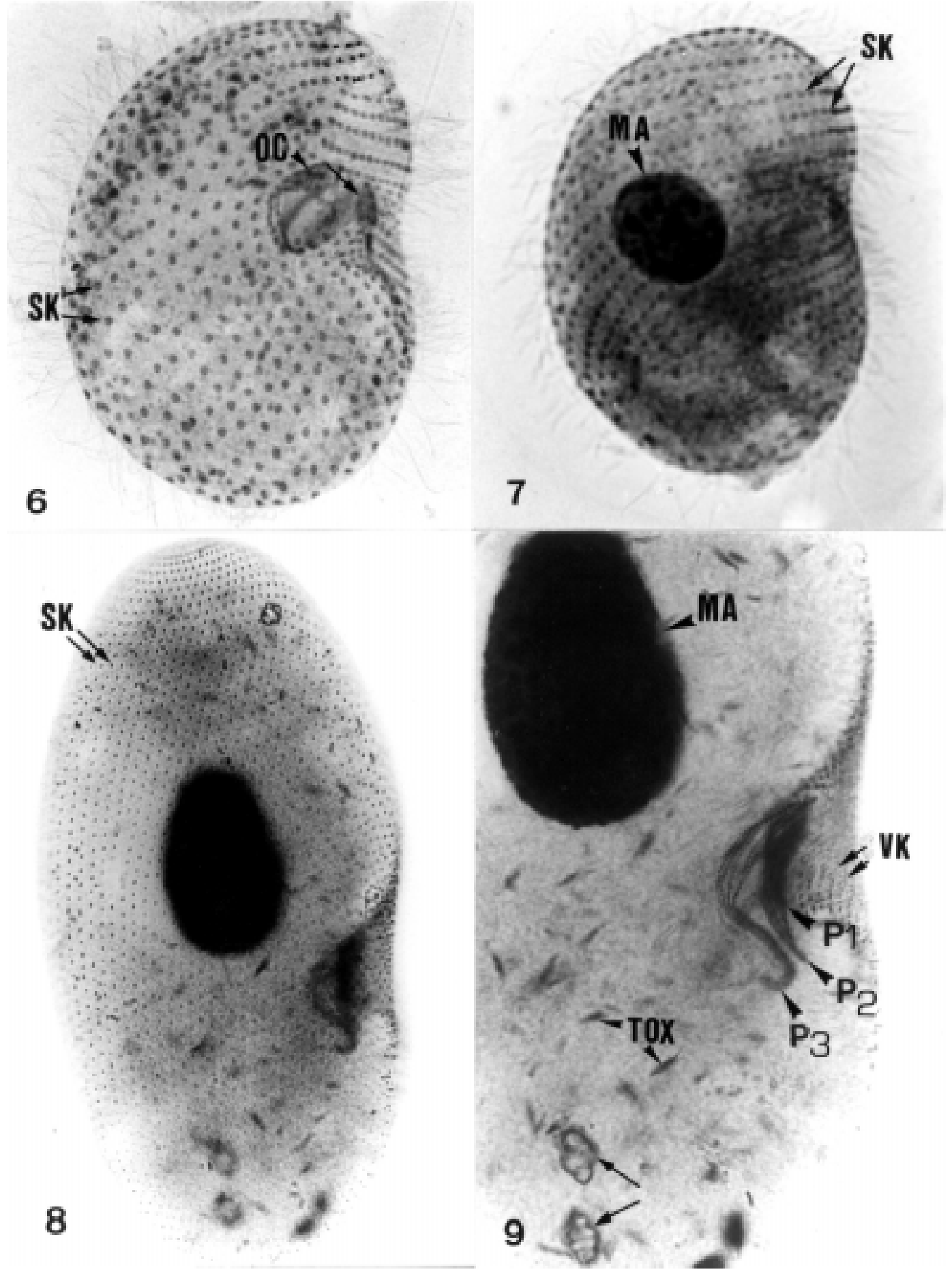

Figs. 6 and 7 - Protargol impregnation of Colpoda cucullus. Ventral face (Fig. 6) and dorsal face (Fig. 7) Colpoda ciliate, soil typical, found in the air conditiconal filter in the cyst form. After fixation the cells were attached on the slides with polylysina before silver impregnation. SK - Somatic Kineties; OC - Oral Ciliature; MA - Macronucleus. Figs. 8 and 9 Protargol impregnation of Paramecium aurelia. General view ventral face (Fig. 8) and detail oral ciliature (Fig. 9). Peniculina ciliate from polluted water from Piratininga's Lagoon, Piratininga, Niterói. The oral ciliature is formed of three peniculus (P1, P2, P3), SK - Somatic Kineties MA - Macronuclei, TOX - Toxcysts, VK - Vestibular Kineties. 

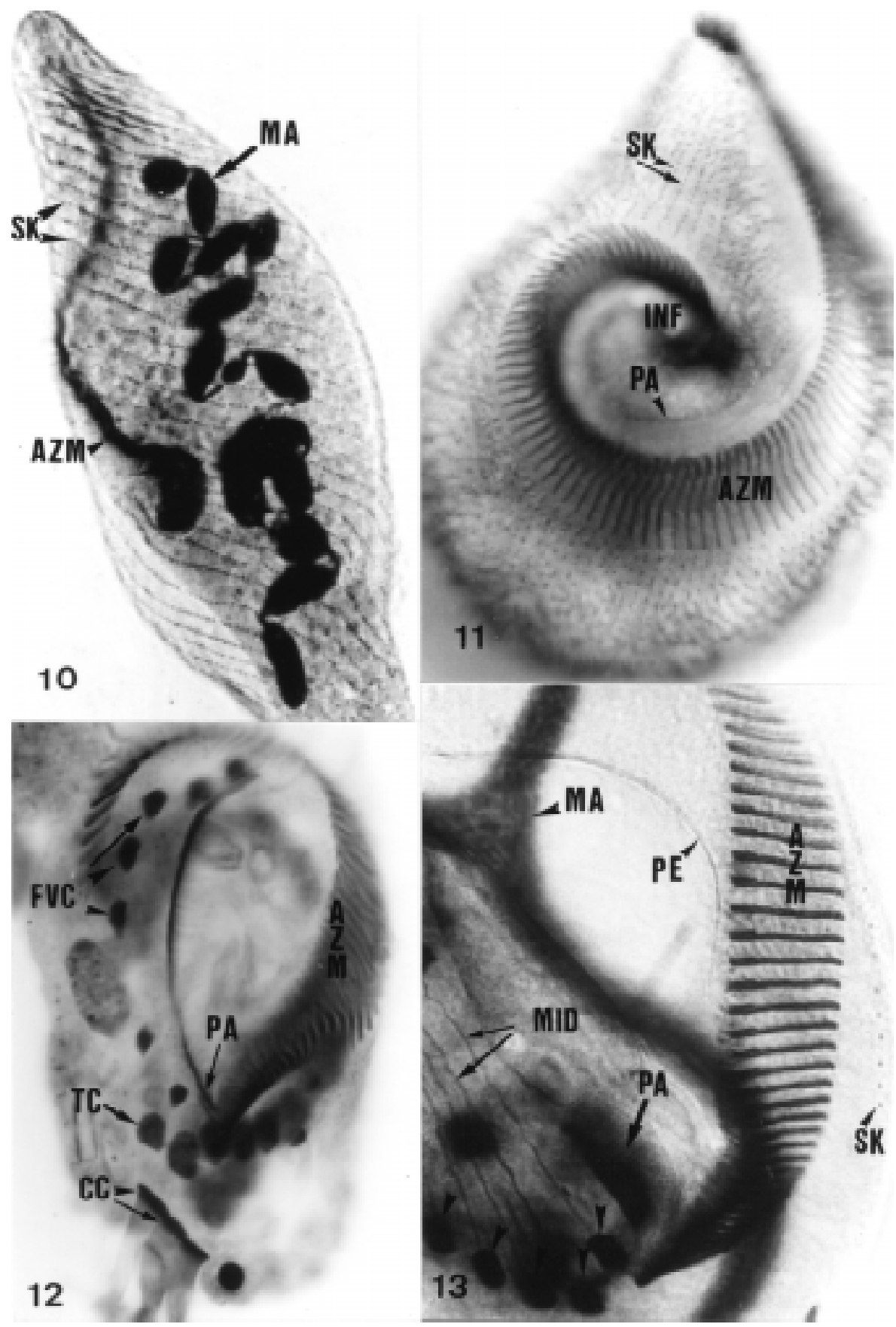

Fig. 10 - Protargol impregnation of Spirostomum minus. Heterotrichida ciliate from fresh water. The somatic kineties (SK) are spiral form due cell contraction after fixation. Adoral Zone of Membranelles and MA - Macronucleus moniliform. Fig. 11 - Protargol impregnation of Fabrea salina. Ventral face of Heterotrichida ciliate colected from Araruama's Lagoon, Araruama, Rio de Janeiro. The oral ciliature (OC) into of infundibulum (INF) is constituted of Adoral Zone of Membranelles (AZM) and Paraoral (PA). SK - Somatic Kineties. Fig. 12 - Protargol impregnation of Diophrys appendiculata. Ventral face Hipotrichida ciliate from Baía de Guanabara's sand, Rio de Janeiro. Details of the Adoral Zone of Membranelles (AZM), Paraoral (PA), Frontal Ventral Cirri (FVC), Transverse Cirri (TC) and Caudal Cirri (CC). Fig 13 - Protargol impregnation of Euplotes Woodruffi. Ventral face of Hipotrichida ciliate showing details of Adoral Zone of Membranelles (AZM) part, Macronucleus (MA), Paraoral (PA), Peristome(PE), Transverse Cirri (arrows) with its Microtubular Derived (MID) associated a Somatic Kinety (SK) dorso-lateral. 
The modifications of the technique described by several researchers (Dieckerman, 1995; Dragesco, 1962; Foissner, 1991; Hiller, 1991; McCoy, 1974; Montagnes \& Lynn, 1987; Moskowitz, 1950; Ng \& Nielsen, 1977; Repak \& Cribbins, 1966; Tuffrau, 1964, 1967; Wilbert, 1975; Zagon, 1970), were made for optimal results and adapted to the material available in their laboratories, thanks to a vast possibility of variation of the technique.

Tuffrau $(1964,1967)$ suggest that a minimum of albumin-glycerol of Mayer solution should be used to attach the cells in the slide, diluted in a proportion of $1: 10$, to form a very fine layer on the slide. The addition of the albumin-glycerol of Mayer on the cells can be done directly on the slide or in a small glass recipient or clock glass; in this case, after homogenization, the cells are distributed diluted in Mayer solution over several slides or coverslips. It is adequate the attachment of the cells in coverslips, to facilitate posterior observation under the microscope of both faces of the impregnated specimen.To avoid the detachment of the cells during the processing of the technique, Tuffrau (1967) suggest the immersion of the slides in the alcool-formol v/v, for 3 minutes. Foissner (1991) suggest the use of the albumin-glycerol after a month of stability in the refrigerator. For the attachment of the cells on the slides or coverslips is adequate as an alternative, the use of polylysine. Which was not used before in the impregnation technique.

The time of impregnation of the cells may vary, as well as the temperature of the incubator.

The concentration of the hydroquinone can be from $0.4 \%$ to $1 \%$. It is adequate a lower concentration. The preparation should be revealed first at very short times and after, the tonality of the impregnation controlled under the microscope. The recommended tonality resembles the color of Whisky. Tuffrau suggests a imersion in 5\% sodium thiosulfate, if the specimens are too dark.

The fixation of the impregnation in sodium thiosulfate should be made between 30 seconds and one minute. Because this may darken the preparation, this stage is very important for the preservation of the impregnated cells for long term storage of the slides in collections.

Finally is adequate the use of the Entellan in stead of balsam from Canada for the mounting of the slides.
In addition to the technique of the protargol, other impregnation techniques by silver can be used, such as the technique of Chatton \& Lwoff (1930), of Klein (1915) and of Fernando-Galeano (1976), that also offer great results in the revelation of important morphological data. But the first, which reveals most of the structures of the cortex of the cell very well, does not evidence the organelles and nuclei of endoplasma. Klein's technique, also called dry silver, does not reveal the whole structures of the cortex, but it evidences the plates of the submembranal cytoskeleton, that exist in several ciliates species. These structures are not very proeminent with protargol, that complements the study of certain protista species. The technique of Fernando-Galeano, also called the technique of the carbonate of silver amoniacal, offers great results like protargol, but it does not allow the preparation of definitive slides for storage in collections. It is necessary to underline that the results of the technique of the protargol are complements of the observation of the protozoan in vivo.

Acknowledgments - I would like to thank the trainees of the laboratory (Anderson Bruno de Matos, Flávio Joppert, Fábio Lima Custódio and Maurício Guimarães Gomes Moreira) and to Prof. Ulisses Lins of the Section of Electronic Microscopia of Inst. of Microbiology-UFRJ, for the access to the optical Microscope Axioplan II of Zeiss, in which the photomicrographs of this work were taken. The work was developed with support of the CNPq (520901/95-9), PRONEX (0877) FAPERJ (E-26/ 170.583/95) and CPEG-UFRJ (351905P077-8).

\section{REFERENCES}

Aufderheide, K. J., 1982, An improvement in the protargol technique of Ng and Nelsen., Trans. Am. Microsc. Soc., 101: 100-104.

Bodian, D., 1936, The new method for staining nerve fibers and nerve endings in mounted paraffin sections. Anat. Rec., 65: 89.

Bodian, D., 1937, The staining of paraffin sections of nervous tissue with activated Protargol. The roles of fixatives. Anat. Rec., 69: 153-162.

Chatton, E. \& Lwoff, A., 1930, Imprégnation par diffusion argentique de 1'infraciliature des ciliés marins et d'eau douce, après fixation cytologique et sans dessication. $C$. R. Soc. Biol., 104: 834-836.

Dieckmann, J., 1995, An improved protargol impregnation for ciliates yielding reproducible results. Europ. J. Protistol., 31, 372-382.

Dragesco, J., 1962, L'orientation actuelle de la systématique des ciliés et la technique d' imprégnation au protéinate d'argent. Bull. Micr. Appl., 11: 49-58. 
Dragesco, J. \& Dragesco-Kernéis, A., 1986, Ciliés libres de l'Afrique intertropicale. Faune tropicale, p. 559.

Fernando-Galeano, D., 1976, Silver impregnation of ciliated Protozoa: Procedure yielding goal results with the pyridinated silver Carbonated Method., Trans. Amer. Microsc. Soc., 95(4): 557-560.

Foissner, W., 1991, Basic light and scanning electron microscopic methods for taxonomic studies of ciliated protozoa. Europ. J. Protistol., 27: 313-330.

Hiller, S. A., 1991, Bursellopsis spaniopogon n. spec. (Ci1iophora: Prostomatida). I. Infraciliature and ultrastructure of the somatic and oral cortex. Europ. J. Protistol., 27: $1-16$.

Klein, B. M., 1958, The "dry" silver method and its proper uses. J. Protozool., 5: 99-103.

McCoy, J. W., 1974, New features of the Tetrahymenid cortex revealed by protargol stainning. Acta Protozool., 13: 155160.

Montagnes, D. J. S. \& Lynn, D. H., 1987, A Quatitative Protargol Stain (QPS) for ciliates: method description and test of its quantitative nature. Marine Microbial Food Webs, 2: 83-93.
Moskowitz, N., 1950, The uses of protein silver for staining protozoa. Stain Technol., 25: 17-20.

Ng, S. F. \& Nelsen, E. M., 1977, The protargol staining technique: an improved version for Tetrahymena pyriformis. Trans. Am. Microsc. Soc., 96: 369-376.

Tuffrau, M., 1964, Quelques variant techniques de 1'imprégnation des ciliés par le protéinate d'argent. Archs. Zool. Exp. Gén., 104: 186-190.

Tuffrau, M., 1967, Perfectionements et pratique de la techinique d'impregnatiom au protargol des infusoires ciliés. Protistologica, 3: 369-399.

Wilbert, N., 1975, Eine verbesserte Technik der Protargolimpragnation fur Ciliaten. Mikrokosmos, 6: 171-179.

Zagon, I. S., 1970, Carchesium polypinum: cytostructure after protargol silver deposition. Trans. Am. Microsc. Soc., 89: 450-468. 